\title{
Rapid detection of bovine milk in yak milk using a polymerase chain reaction technique
}

\author{
W. L. Bai, ${ }^{*}$ R. H. Yin, ${ }^{*}$ S. J. Zhao, Q. L. Dou,§ J. C. Yang, ${ }^{*}$ W. Q. Jiang, ${ }^{*}$ Z. H. Zhao,† and G. B. Luo*1 \\ ${ }^{*}$ College of Animal Science and Veterinary Medicine, Shenyang Agricultural University, Shenyang 110161, China \\ †College of Animal Science and Veterinary Medicine, Jilin University, Changchun 130062, China \\ $\ddagger$ Animal Science Research Academy of Sichuan Province, Chengdu 610066, China \\ §College of Agricultural and Animal Husbandry, Qinghai University, Xining 810016, China
}

\begin{abstract}
Yak milk contains a greater percentage of protein and has better quality than bovine milk. There has been an increasing focus on yak milk and milk products during the last few years. In the present study, a PCR-based assay was developed for the specific identification of bovine milk in yak milk by designing 3 primers targeting the mitochondrial ND1 gene. The use of 3 primers in a single PCR reaction set yielded 2 amplification fragments of 293 and 190 bp from bovine milk DNA, whereas only 1 amplification fragment of $293 \mathrm{bp}$ was obtained in yak milk DNA. The technique was applied to raw and heat-treated binary mixtures of yak and bovine milks and enabled the specific detection of bovine milk with a detection limit of $0.1 \%$. The assay developed is sensitive, fast, and straightforward, and it might be useful in the quality control of yak milk and milk products.
\end{abstract}

Key words: yak milk, bovine milk, ND1 gene, polymerase chain reaction

\section{INTRODUCTION}

The yak has been regarded as one of the most remarkable domestic animals, because it thrives in conditions of extreme harshness while providing a livelihood for people with milk, meat, fur, and other products (Sasaki, 1994; Wiener et al., 2003). Yak milk has a better quality (i.e., it contains a greater percentage of protein) compared with bovine milk (Wang and Zou, 1995). Thus, there has been an increasing focus on yak milk and milk products in recent years (Fan et al., 2000). In general terms, however, the milk yield of yak is relatively low compared with that of the bovine. Therefore, to prevent the adulteration of yak milk with bovine milk, it is necessary to develop a rapid and sensitive method for the identification of bovine milk in

Received September 17, 2008.

Accepted November 18, 2008.

${ }^{1}$ Corresponding author: gbluo@yahoo.cn yak milk to ensure the quality of yak milk and milk products.

To date, various different approaches have been developed for the identification of animal origin of food products, such as 2-dimensional electrophoresis (Chianese et al., 1990), isoelectric focusing (Addeo et al., 1990; Moio et al., 1990), capillary electrophoresis (Molina et al., 1999; Recio et al., 2004), HPLC (De Noni et al., 1996; Mayer et al., 1997; Moatsou et al., 2004), ELISA (Haza et al., 1997; Richter et al., 1997; Hurley et al., 2004a,b), and chromatographic techniques (Urbanke et al., 1992; Torre et al., 1996; Bramanti et al., 2001). Most of these techniques proved to be effective and were widely put into practice. Chromatographic methods can detect differences in the percentages of the fatty acids but are laborious (Branciari et al., 2000), and protein-based methods may fail in the analysis of heat-treated materials (Reale et al., 2008).

More recently, DNA-based techniques, especially PCR-based methods, for the identification of the animal origin of food products have received particular attention and have proved to be reliable, sensitive, and fast (Colgan et al., 2001; Rodríguez et al., 2002; Bottero et al., 2003; Dalmasso et al., 2004; López-Calleja et al., 2005).

Ruminant milk contains somatic cells including leukocytes and epithelial mammary cells. Studies have demonstrated that these cells can be used as a DNA source to discriminate animal species by PCR amplification of specific target sequences (Lipkin et al., 1993; Amills et al., 1997; Maudet and Taberlet, 2001). The purpose of the present work was to develop a fast, sensitive, and straightforward protocol for the detection of bovine milk in yak milk by targeting the ND1 gene of mitochondrial DNA.

\section{MATERIALS AND METHODS}

\section{Milk Samples and DNA Extraction}

Raw milks from bovine (Bos taurus) and yak (Bos grunniens) were collected from local farmer. The milk 


\begin{tabular}{|c|c|c|c|}
\hline & & $B O / Y A-F W$ & \\
\hline Bovine & 1 & GAAAAGGTCCAAATGTCGTAGGTCCATATGGCCTACTTCAACCCATCGCC & 50 \\
\hline ak & 1 & GAAAAGGTCCAAATGTCGTAGGCCCATATGGCCTACTCCAACCCATCGCC & 50 \\
\hline vine & 51 & GATGCAATCAAACTTTTCATTAAAGAACCACTACGACCCGCTACATCTTC & 100 \\
\hline ak & 51 & GATGCAATCAAACTTTTCATCAAAGAACCATTACGACCTGCCACGTCTTC & 100 \\
\hline & & $B O-F W$ & \\
\hline vine & 101 & AGCCTCAATATTTATCCTAGCACDTATCATAGCTTTAGGCCTAGCCTTAA & 150 \\
\hline$k$ & 101 & AACCTCAATATTCATCCTAGQGCQCATITIIAGCTCTAGGCCTAGCCTTAA & 150 \\
\hline vine & 151 & 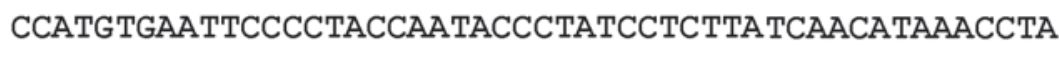 & $20 \mathrm{C}$ \\
\hline k & 151 & 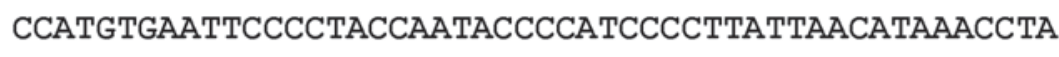 & $20 \mathrm{C}$ \\
\hline vine & 201 & GGAGTCCTATTTATACTAGCCATATCAAGCCTAGCCGTATACTCCATTCT & \\
\hline & 201 & $\begin{array}{c}\text { GGAGTCCTATTTATACTAGCAATATCAAGCCTAGCCGTGTACTCCATCCT } \\
\text { BO/YA-RV }\end{array}$ & 50 \\
\hline & 251 & СTGATCAGGCTGAGCTTCCAACTCAAAATACGCACTAATCGGA 293 & \\
\hline & 251 & 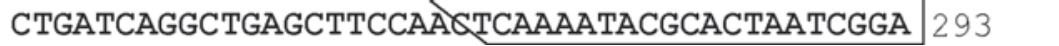 & \\
\hline
\end{tabular}

Figure 1. Sequence alignment of $N D 1$ gene fragment from bovine and yak. Large open arrows indicate the 2 primers common to both bovine and yak $(B O / Y A-F W$ and $B O / Y A-R V)$; the narrow black arrow indicates the bovine-specific primer $(B O-F W)$. In the position of primer $B O$ $F W$, nucleotides that differ between bovine and yak are boxed.

samples were transported to the laboratory under refrigeration and were stored frozen at $-20^{\circ} \mathrm{C}$ until analyzed.

Bovine milk, yak milk, and mixtures of yak milk mixed with bovine milk were prepared for DNA extraction and PCR amplification in the following percentages $(\%, \mathrm{vol} / \mathrm{vol}): 50: 50,80: 20,90: 10,95: 5,97.5: 2.5$, 99:1, 99.5:0.5, and 99.9:0.1. In addition to raw milk, we also analyzed pasteurized $\left(65^{\circ} \mathrm{C}, 30 \mathrm{~min}\right)$ and sterilized $\left(121^{\circ} \mathrm{C}, 20 \mathrm{~min}\right)$ milks (López-Calleja et al., 2004). We extracted DNA from raw and heat-treated milk mixtures according to the described method of López-Calleja et al. (2004). The DNA concentration of each sample was estimated by spectrophotometry at $260 \mathrm{~nm}$.

\section{Primer Design}

The mitochondrial ND1 gene was selected as the target sequence based on the information obtained from the alignment of mitochondrial DNA complete sequences of bovine and yak in GenBank (bovine: accession no. AF492351, AY526085, AB074962, AY676857, and AB074963; yak: accession no. AY684273, EF494177, EF494178, and EF494179). A pair of primers (BO/ $\boldsymbol{Y A}-\boldsymbol{F} \boldsymbol{W}:$ 5'-GAAAAGGTCCAAATGTCGTAGGT-3' and $\boldsymbol{B O} / \boldsymbol{Y A}-\boldsymbol{R} \boldsymbol{V}:$ : 5'-TCCGATTAGTGCGTATTTTGAGT-3') targeting the ND1 gene with $100 \%$ homology between bovine and yak were designed. This set of primers was expected to yield a 293-bp fragment in both bovine and yak. In addition, a bovine-specific extension primer $(\boldsymbol{B} \boldsymbol{O}-\boldsymbol{F} \boldsymbol{W}$ : 5'-CTCAATATTTATCCTAGCACCTATCA-3') was designed in the potential amplification region of $B O / Y A-F W$ and $B O / Y A-R V$ primers (Figure 1).

Combination of the $B O-F W$ and $B O / Y A-R V$ primers was expected to amplify a 190-bp fragment in bovine but not in yak because of the mismatches of the $B O-F W$ primer, which provides the unambiguous determination of bovine and yak. The 293-bp fragment amplified by $B O / Y A-F W$ and $B O / Y A-R V$ primers common to both bovine and yak acts as a positive control in practical milk detection.

The suitability of the primer sets designed in the present work was confirmed by challenging them with milk DNA of different breeds of bovine (Chinese Holstein, Caoyuan Red, and Sanhe) and yak (Tianzhu White, Maiwa, Jiulong, and Datong) in preliminary PCR amplification experiments.

\section{PCR Amplification}

After the suitability of the designed primer sets was evaluated, raw and heat-treated binary mixtures of yak milk containing different amounts of bovine milk were tested for the expected DNA fragment amplification.

The PCR reaction was performed in a final volume of $25 \mu \mathrm{L}$ containing $1 \mathrm{U}$ of AmpliTaq Gold DNA polymerase (Applied Biosystems, Branchburg, NJ), $1 \times$ 


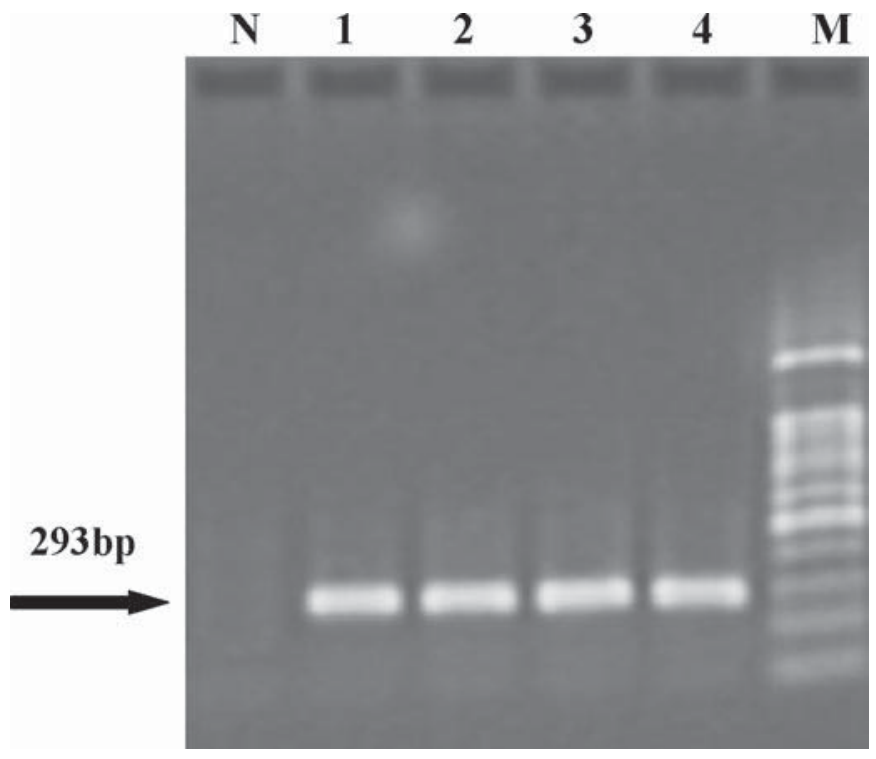

Figure 2. Electrophoretic analysis of the ND1 gene PCR amplification fragments obtained from bovine (lane 1 and 3 ) and yak (lane 2 and 4) milk DNA using primers $B O / Y A-F W$ and $B O / Y A-R V$. M = molecular weight marker, 100-bp DNA ladder (TaKaRa, Dalian, China); $\mathrm{N}=$ negative control.

PCR buffer (TaKaRa, Dalian, China), $1.5 \mathrm{mM} \mathrm{MgCl}$, $200 \mu M$ of each dNTP, 10 pmol of each primer, and 100 ng of template DNA. Amplification was carried out in a TC-512 Gradient Thermal Cycler (Techne, Stone, UK) with the following program: initial denaturation step at $95^{\circ} \mathrm{C}$ for $12 \mathrm{~min}, 30$ cycles at $95^{\circ} \mathrm{C}$ for $30 \mathrm{~s}, 60^{\circ} \mathrm{C}$ for 30 $\mathrm{s}, 72^{\circ} \mathrm{C}$ for $30 \mathrm{~s}$, and a final extension at $72^{\circ} \mathrm{C}$ for $5 \mathrm{~min}$. The PCR products were resolved by electrophoresis on a 1.5\% agarose gel at $100 \mathrm{~V}$ for $40 \mathrm{~min}$ and stained with ethidium bromide.

To investigate the detection limit of the protocol developed in the present work, each binary milk mixture of bovine and yak milks containing bovine milk ranging from 0.1 to $50 \%$ (vol/vol) was subjected to PCR amplification, and the obtained products were detected by agarose gel electrophoresis.

\section{Cloning and Sequencing of PCR Products}

The PCR products of the expected length from DNA extracted from bovine and yak milk using the $B O / Y A$ $F W$ and $B O / Y A-R V$ primers were purified and cloned into the pMD18-T vector (TaKaRa), and then transformed into competent Escherichia coli DH5a cells. The identified positive clone with the ND1 gene fragment was sequenced by an ABI Prism 377 DNA sequencer (Perkin-Elmer Cetus Instruments, Norwalk, CT). The sequence alignments and comparisons were carried out with Bioedit software (Hall, 1999).

\section{RESULTS}

In the present work, an assay based on PCR was developed for rapid detection of bovine milk in yak milk. Based on the information obtained after alignment of mitochondrial $N D 1$ gene from bovine and yak in GenBank, a pair of primers $B O / Y A-F W$ (forward) and $B O / Y A-R V$ (reverse) targeting the $N D 1$ gene were designed with 100\% homology between bovine and yak. This set of primers was expected to yield a 293bp fragment in the ND1 gene of both bovine and yak. As observed in Figure 2, the expected PCR fragment (293 bp) was successfully amplified with the $B O / Y A$ $F W$ and $B O / Y A-R V$ primer pair in bovine and yak. In addition, a bovine-specific forward primer $B O-F W$ was designed in the potential amplification region of $B O / Y A-F W$ and $B O / Y A-R V$ primers. This primer, along with the conserved reverse $B O / Y A-R V$ primer, was expected to amplify a bovine-specific fragment of 190 bp in the ND1 gene. As can be seen in Figure 3, the DNA extracted from bovine milk was successfully amplified with the $B O-F W$ and $B O / Y A-R V$ primer pair, yielding the expected amplification fragment of 190 bp, but no amplification signals were observed with the DNA extracted from yak milk samples because of the mismatches of $B O-F W$ primer, which provides the unambiguous determination of bovine and yak milk.

When PCR amplifications were performed using 3 primers $(B O / Y A-F W, B O-F W$, and $B O / Y A-R V)$ in a single reaction set, the DNA from bovine milk yielded 2 amplification fragments (293 and $190 \mathrm{bp}$ ), whereas

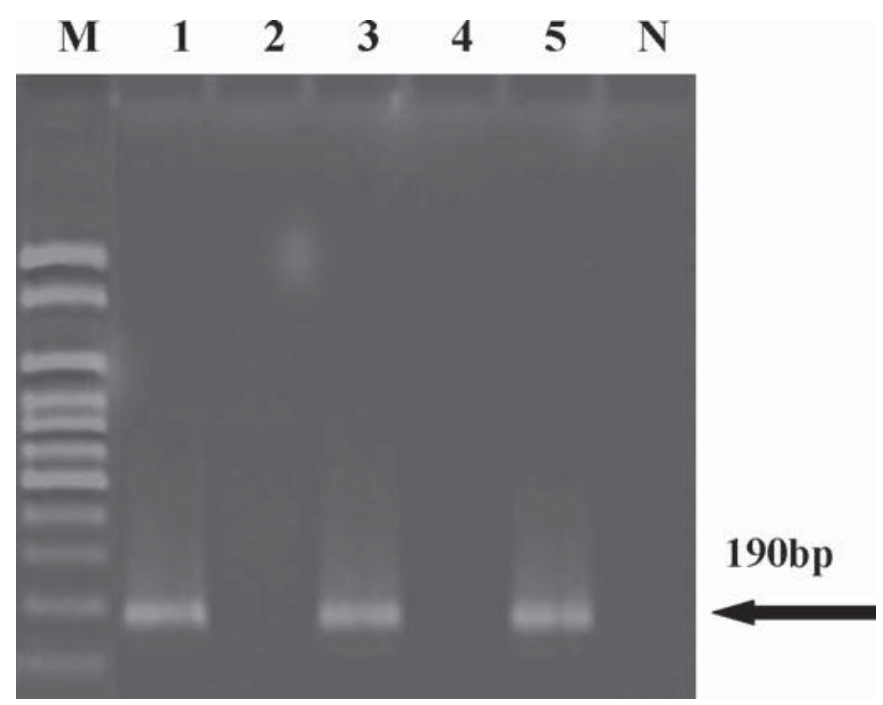

Figure 3. Electrophoretic analysis of the bovine-specific $N D 1$ gene amplification from milk samples using primers $B O-F W$ and $B O / Y A$ $R V$. Samples are bovine (lanes 1, 3, and 5) and yak (lanes 2 and 4 ). $\mathrm{M}=$ molecular weight marker, 100-bp DNA ladder (TaKaRa, Dalian, China); $\mathrm{N}=$ negative control. 


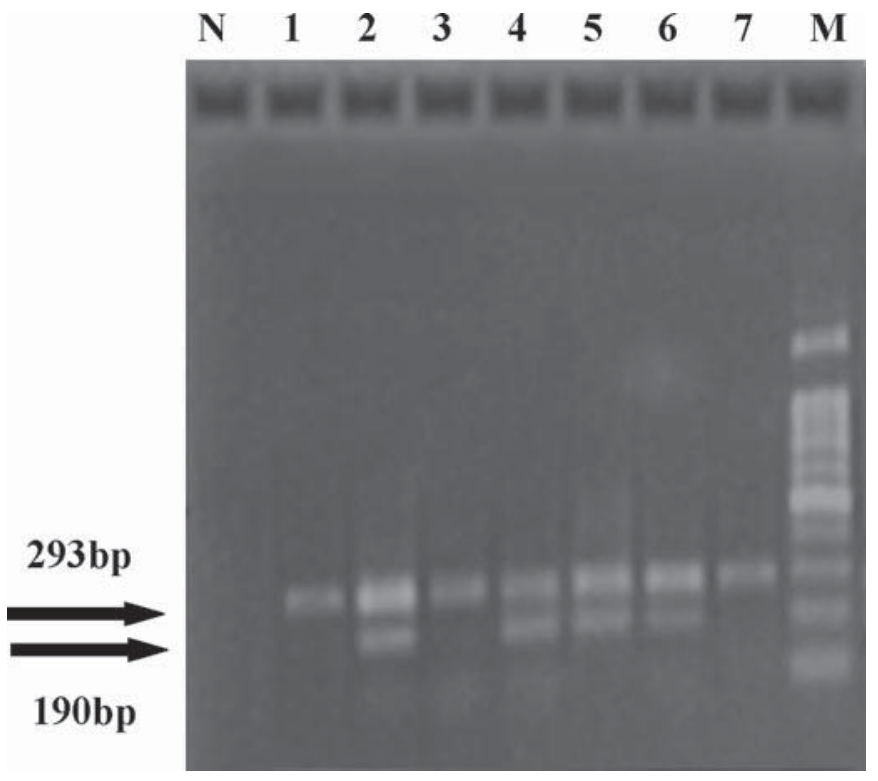

Figure 4. Electrophoretic analysis of the ND1 gene PCR amplification fragments obtained from bovine (lane 2), yak (lanes 1, 3, and 7), and binary mixture of bovine/yak milk containing $50 \%$ (lane 4 ), $20 \%$ (lane 5), and $5 \%$ (lane 6) bovine DNA using primers $B O / Y A-F W$, $B O-F W$, and $B O / Y A-R V . \mathrm{M}=$ molecular weight marker, 100-bp DNA ladder (TaKaRa, Dalian, China); $\mathrm{N}=$ negative control.

the DNA from yak milk yielded only 1 amplification fragment of 293 bp (Figure 4). Moreover, similar amplification patterns to those obtained for the DNA from bovine milk were generated on the DNA extracted from binary raw milk mixtures (bovine in yak) containing 5 , 20, and $50 \%$ (vol/vol) bovine milk. Thus, the bovinespecific amplification fragment of $190 \mathrm{bp}$ can be used to detect the presence of bovine milk in yak milk, and the 293-bp fragment common to bovine and yak acts as a positive control in practical milk detection.

To investigate the detection limit of the assay developed in this study, each binary milk mixture of bovine/ yak milk containing bovine milk at a range of percentages, $(50,20,10,5,2.5,1,0.5$ and $0.1 \%$, vol $/ \mathrm{vol})$ was subjected to PCR amplification, and the obtained products were detected by agarose gel electrophoresis. As shown from Figure 5, for the bovine-specific 190-bp fragment generated on the DNA from binary milk mixtures of bovine/yak, the band intensity was related to the amount of template DNA, and the lowest percentage of bovine milk in yak milk obtained was $0.1 \%$.

For the purpose of investigating the applicability of the assay to heat-treated milk, 30 milk samples including raw milk, pasteurized milk $\left(65^{\circ} \mathrm{C}, 30 \mathrm{~min}\right)$, and sterilized milk $\left(121^{\circ} \mathrm{C}, 20 \mathrm{~min}\right)$ were prepared and tested using the assay developed in the present work. The results obtained are listed in Table 1 . As shown in Table 1, the 2 amplification bands of $293 \mathrm{bp}$ (com- mon to bovine and yak) and $190 \mathrm{bp}$ (bovine-specific) were always present in the pure bovine milk and binary mixtures of yak/bovine milk, whereas only the 293-bp band was present in the samples of pure yak milk (the bovine-specific 190-bp band was absent). Moreover, the amplification patterns and detection limits were similar among raw, pasteurized, and sterilized milks, suggesting that the assay developed also applies to DNA from heat-treated milk and milk products. In addition, 3 milk samples (no. 4, 12, and 25) failed to generate the expected bands of 293 and $190 \mathrm{bp}$, because DNA polymerase was deliberately not added in the 3 PCR reaction sets, which means that a negative result indicates experimental error.

\section{DISCUSSION}

In recent years, numerous methods based on DNA detection have been developed for the identification of animal origin of food products, most of which are based on specific PCR amplification of mitochondrial or nuclear DNA (Bania et al., 2001; Maudet and Taberlet, 2001; Rea et al., 2001; Bottero et al., 2002; Mafra et al., 2004). In the present work, a PCR assay for rapid detection of bovine milk in yak milk was developed using 3 primers designed to target the mitochondrial

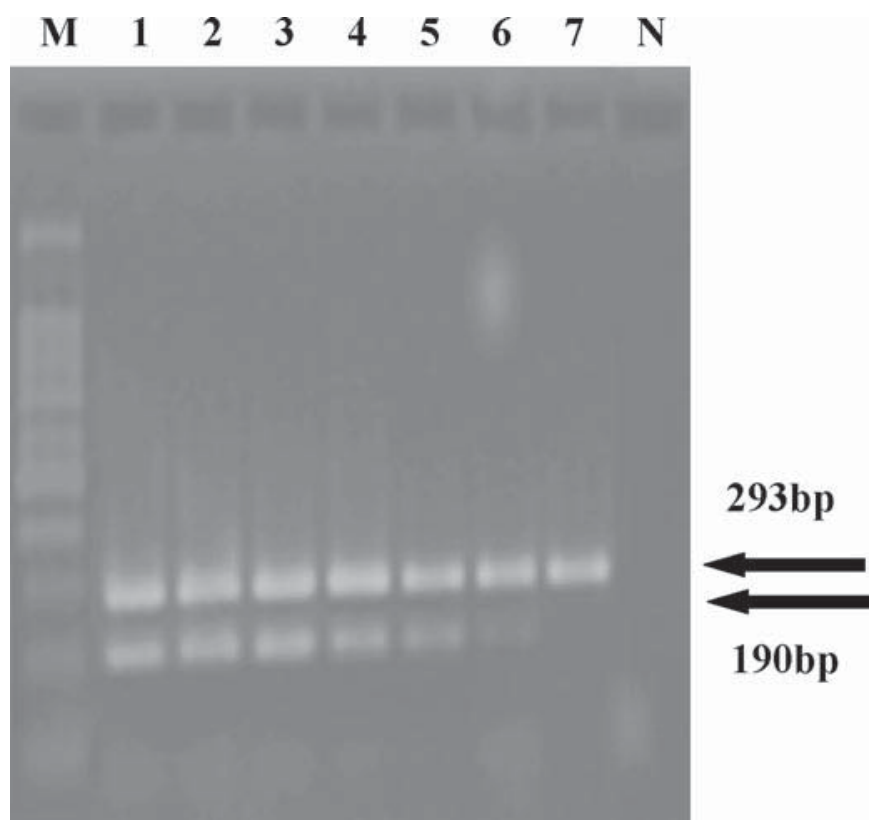

Figure 5. Electrophoretic analysis of the ND1 gene PCR amplification fragments obtained from raw milk binary mixtures of bovine in yak by using primers $B O / Y A-F W, B O-F W$, and $B O / Y A-R V$. Samples are $100 \%$ bovine (lane 1), $10 \%$ bovine (lane 2), $5 \%$ bovine (lane 3 ), $1 \%$ bovine (lane 4 ), $0.5 \%$ bovine (lane 5 ), $0.1 \%$ bovine (lane 6 ), and $100 \%$ yak (lane 7 ). M = molecular weight marker, 100-bp DNA ladder (TaKaRa, Dalian, China); $\mathrm{N}=$ negative control. 
Table 1. List of 30 milk samples tested in this study by using the assay developed and the results obtained ${ }^{1}$

\begin{tabular}{|c|c|c|c|c|}
\hline Milk sample no. & $\begin{array}{l}\text { Type of } \\
\text { milk sample }\end{array}$ & $\begin{array}{l}\text { Proportion of binary milk } \\
\text { mixture (yak: bovine, \%) }\end{array}$ & \multicolumn{2}{|c|}{ Product of PCR amplification ${ }^{3}$} \\
\hline 1 & RA & 0: 100 & Present & Present \\
\hline 3 & RA & 80: 20 & Present & Present \\
\hline 4 & RA & 90: 10 & Absent & Absent \\
\hline 5 & RA & $95: 5$ & Present & Present \\
\hline 9 & RA & 99.9: 0.1 & Present & Present \\
\hline 10 & RA & 100: 0 & Present & Absent \\
\hline 11 & PA & 0: 100 & Present & Present \\
\hline 12 & $\mathrm{PA}$ & 50: 50 & Absent & Absent \\
\hline 13 & PA & 80: 20 & Present & Present \\
\hline 14 & PA & 90: 10 & Present & Present \\
\hline 20 & PA & 100: 0 & Present & Absent \\
\hline 21 & ST & 0: 100 & Present & Present \\
\hline 22 & ST & 50: 50 & Present & Present \\
\hline 23 & ST & 80: 20 & Present & Present \\
\hline 24 & ST & 90: 10 & Present & Present \\
\hline 25 & ST & $95: 5$ & Absent & Absent \\
\hline 26 & ST & $97.5: 2.5$ & Present & Present \\
\hline 27 & ST & 99: 1 & Present & Present \\
\hline 28 & ST & $99.5: 0.5$ & Present & Present \\
\hline 29 & ST & 99.9: 0.1 & Present & Present \\
\hline 30 & ST & 100: 0 & Present & Absent \\
\hline
\end{tabular}

${ }^{1}$ Milk sample nos. 4, 12, and 25 failed to provide the expected bands of 293 and 190 bp because DNA polymerase was deliberately not added in the $3 \mathrm{PCR}$ reaction sets.

${ }^{2} \mathrm{RA}=$ raw milk; $\mathrm{PA}=$ pasteurized milk; and $\mathrm{ST}=$ sterilized milk.

${ }^{3}$ Presence and absence of 293- or 190-bp bands in the tested samples.

ND1 gene. Theoretically, mitochondrial DNA has some advantages over nuclear DNA (Unseld et al., 1995). The greater number of copies of mitochondrial DNA compared with nuclear DNA improve the success and yield of DNA extraction in any given sample. On the other hand, compared with nuclear DNA, the relatively higher mutation rate has resulted in the accumulation of a wide range of base substitutions in mitochondrial DNA making it easier to identify species differences. Therefore, the ND1 gene encoded by mitochondrial DNA was selected to identify bovine and yak in this study.

The 3 primers $B O / Y A-F W, B O-F W$, and $B O / Y A-R V$ were designed based on the sequence alignment of the ND1 gene of bovine and yak available in GenBank. The suitability of the primer pair amplification was verified on DNA extracted from milk samples of different breeds of bovine (Chinese Holstein, Caoyuan Red, and Sanhe) and yak (Tianzhu White, Maiwa, Jiulong, and Datong), and the sequencing analysis of the amplicons of primer pair $B O / Y A-F W$ and $B O / Y A-R V$ revealed the expected haplotypes for bovine and yak. Theoretically, DNA might undergo denaturation at elevated temperature and other processing treatments of milk and milk products. To improve the amplification chances for the DNA extracted from heat-treated or processed milk and milk products that might be degraded, the length of amplified fragments was restricted to within 300 bp (293 and $190 \mathrm{bp}$ ) in this work. The assay was also tested with both pasteurized $\left(65^{\circ} \mathrm{C}, 30 \mathrm{~min}\right)$ and sterilized $\left(121^{\circ} \mathrm{C}, 20 \mathrm{~min}\right)$ milk. We verified that the method developed applies to DNA extracted from heat-treated milk samples (Table 1). Previously, López-Calleja et al. (2004, 2005) reported the similar results in the detection of cow milk in goat and sheep milk, and of goat milk in sheep milk by amplifying the target sequence of the 12S rRNA gene in mitochondrial DNA. However, in this work, the DNA from other processed milk and milk products (such as cheese) were not tested, assuming that the assay is also applicable to them.

Methods based on PCR have been shown to be a suitable technique in detecting adulteration of food 
products of animal origin (Tartaglia et al., 1998; Partis et al., 2000; Reale et al., 2008). However, PCR itself is so sensitive that suboptimal conditions might provide a negative result even in the presence of the target DNA template (Kudo et al., 1993). Therefore, the use of a positive control is essential in practical use. In this work, the bovine-specific amplification fragment of $190 \mathrm{bp}$ (amplified with primer pair BO-FW and BO/ $Y A-R V$ ) can be used to detect the presence of bovine milk in yak milk, and the 293-bp fragment (amplified with primer pair $B O / Y A-F W$ and $B O / Y A-R V$ common to both bovine and yak) acts as a positive control in practical detection of milk samples. Thus, the samples from pure bovine milk or binary milk mixtures of bovine/yak unequivocally gave 2 amplification fragments of 293 and $190 \mathrm{bp}$, and the samples from pure yak milk provided only a 293-bp fragment (Figure 4); negative results from samples analyzed indicated an experimental error, as seen in the sample numbers 4,12 , and 25 in this study (Table 1).

The sensitivity of the method for detection of bovine milk in yak milk was evaluated using dilutions of milk samples from bovine and yak. Figure 5 shows that the lower the percentage of bovine milk in the binary milk mixtures of bovine and yak, the fainter the 190-bp bovine-specific band in the agarose gel. The lowest milk percentage (amplifying a visible band of $190 \mathrm{bp}$ on agarose gel stained with ethidium bromide) was $0.1 \%$ bovine milk in the binary milk mixture. The detection limit obtained from heat-treated milk samples was not modified substantially compared with raw milk mixtures. The same detection limit of $0.1 \%$ was obtained in detection of cow milk in goat milk and sheep (López-Calleja et al., 2004), of cow milk in goat cheese (Maudet and Taberlet, 2001), and of goat milk in sheep milk (López-Calleja et al., 2005) by amplifying the target sequence of mitochondrial DNA, being lower than that obtained using a duplex PCR methods for identification of cow milk in goat and sheep milk in dairy products (Bottero et al., 2003). The latter allowed the detection of $0.5 \%$ cow milk.

In the present work, a PCR-based assay able to detect bovine milk in yak milk with a detection limit of $0.1 \%$ was developed by amplifying the target sequence of the ND1 gene in mitochondrial DNA. The assay proved to be sensitive, fast, and straightforward. Two PCR fragments, a bovine-specific PCR fragment and a PCR fragment present in both bovine and yak, can be detected simultaneously in a single reaction set. To our knowledge, this is the first description of a method allowing identification of bovine milk in yak milk. The technique might be useful in the quality control of yak milk and milk products and in protecting the interests of consumers.

\section{ACKNOWLEDGMENTS}

We thank J. Wang from Southwest University for Nationalities (Chengdu, China) for valuable guidance and encouragement. We also thank the anonymous reviewers for substantial suggestions in improving this paper.

\section{REFERENCES}

Addeo, F., L. Moio, L. Chianese, C. Stingo, P. Resmini, I. Berner, I. Krause, A. Di Luccia, and A. Bocca. 1990. Use of plasmin to increase the sensitivity of the detection of bovine milk in ovine and/or caprine cheese by gel isoelectric focusing of $\gamma^{2}$-caseins. Milchwissenschaft 45:708-711.

Amills, M., O. Francino, M. Jansa, and A. Sánchez. 1997. Isolation of genomic DNA from milk samples by using Chelex resin. J. Dairy Res. 64:231-238.

Bania, J., M. Ugorski, A. Polanowski, and E. Adamczyk. 2001. Application of polymerase chain reaction for detection of goats' milk adulteration by milk of cow. J. Dairy Res. 68:333-336.

Bottero, M. T., T. Civera, A. Anastasio, R. M. Turi, and S. Rosati. 2002. Identification of cow's milk in "buffalo" cheese by duplex polymerase chain reaction. J. Food Prot. 65:362-366.

Bottero, M. T., T. Civera, D. Nucera, S. Rosati, P. Sacchi, and R. M. Turi. 2003. A multiplex polymerase chain reaction for the identification of cows', goats', and sheep's milk in dairy products. Int. Dairy J. 13:277-282.

Bramanti, E., C. Sortino, G. Raspi, and R. E. Synovec. 2001. Separation and determination of denatured caseins by hydrophobic interaction chromatography. Part II. Method validation and applications. Analyst (Lond.) 126:995-1000.

Branciari, R., I. J. Nijman, M. E. Plas, E. Di Antonio, and J. A. Lenstra. 2000. Species origin of milk in Italian Mozzarella and Greek feta cheese. J. Food Prot. 63:408-411.

Chianese, L., P. Laezza, L. A. Smaldone, C. Stingo, L. Del Giovine, and F. Addeo. 1990. Evaluation of bovine milk in the buffalo Mozzarella cheese by two-dimensional electrophoresis. Sci. Tecn. Latt. Cas. 41:315-326.

Colgan, S., L. O'Brien, M. Maher, N. Shilton, K. McDonnell, and S. Ward. 2001. Development of a DNA-based assay for species identification in meat and bone meal. Fleischwirtschaft 34:409 414.

Dalmasso, A., E. Fontanella, P. Piatti, T. Civera, S. Rosati, and M. T. Bottero. 2004. A multiplex PCR assay for the identification of animal species in feedstuffs. Mol. Cell. Probes 18:81-87.

De Noni, I., A. Tirelli, and F. Masotti. 1996. Detection of cows' milk in non-bovine cheese by HPLC of whey protein: Application to goat milk cheese. Sci. Tecn. Latt. Cas. 47:7-17.

Fan, B. L., N. Li, X. X. Hu, and C. X. Wu. 2000. Cloning, sequencing and polymorphism analyzing of the exon 4 of the kappa-casein gene in yak. Prog. Nat. Sci. 10:769-773.

Hall, T. A. 1999. BioEdit: A user-friendly biological sequence alignment editor and analysis program for Windows 95/98/NT. Nucleic Acids Symp. Ser. 41:95-98.

Haza, A. I., P. Morales, R. Martín, T. García, G. Aguita, I. González, B. Sanz, and P. E. Hernández. 1997. Use of a monoclonal antibody and two enzyme-linked inmunosorbent assay formats for detection and quantification of the substitution of caprine milk for ovine milk. J. Food Prot. 60:973-977.

Hurley, I. P., R. C. Coleman, H. E. Ireland, and J. H. H. Williams. 2004b. Measurement of bovine IgG by indirect competitive ELISA as a means of detecting milk adulteration. J. Dairy Sci. 87:543549.

Hurley, I. P., H. E. Ireland, R. C. Coleman, and J. H. H. Williams. 2004a. Application of immunological methods for the detection of species adulteration in dairy products. Int. J. Food Sci. Technol. 39:873-878. 
Kudo, T., S. Sato, and S. Sutou. 1993. Sexing of bovine embryos with male-specific repetitive DNA by polymerase chain reaction: Cloning and characterization of bovine male-specific repetitive DNA. J. Reprod. Dev. 39:55-63.

Lipkin, E., A. Shalom, H. Khatib, M. Soller, and A. Friedmann. 1993. Milk as a source of deoxyribonucleic acid and as a substrate for the polymerase chain reaction. J. Dairy Sci. 76:2025-2032.

López-Calleja, I., I. González, V. Fajardo, I. Martín, P. E. Hernández, T. García, and R. Martín. 2005. Application of polymerase chain reaction to detect adulteration of sheep's milk with goats' milk. J. Dairy Sci. 88:3115-3120.

López-Calleja, I., I. González, V. Fajardo, M. A. Rodríguez, P. E. Hernández, T. García, and R. Martín. 2004. Rapid detection of cows' milk in sheeps' and goats' milk by a species-specific polymerase chain reaction technique. J. Dairy Sci. 87:2839-2845.

Mafra, I., I. M. P. L. V. O. Ferreira, M. A. Faria, and B. P. P. Oliveira. 2004. A novel approach to the quantification of bovine milk in ovine cheeses using a duplex polymerase chain reaction method. J. Agric. Food Chem. 52:4943-4947.

Maudet, C., and P. Taberlet. 2001. Detection of cows' milk in goats cheeses inferred from mitochondrial DNA polymorphism. J. Dairy Res. 68:229-235.

Mayer, H. K., D. Heidler, and C. Rockenbauer. 1997. Determination of the percentages of cows', ewes' and goats' milk in cheese by isoelectric focusing and cation-exchange HPLC of $\gamma$ - and para- $\kappa$ caseins. Int. Dairy J. 7:619-628.

Moatsou, G., A. Hatzinaki, G. Psathas, and E. Anifantakis. 2004 Detection of caprine casein in ovine Halloumi cheese. Int. Dairy J. $3: 219-226$

Moio, L., M. L. Sasso, L. Chianese, and F. Addeo. 1990. Rapid detection of bovine milk in ovine, caprine and water buffalo milk or cheese by gel isoelectric focusing on phastsystem. Ital. J. Food Sci. 3:185-190.

Molina, E., P. J. Martín-Álvarez, and M. Ramos. 1999. Analysis of cows', ewes' and goats' milk mixtures by capillary electrophoresis: Quantification by multivariate regression analysis. Int. Dairy J. 9:99-105.

Partis, L., D. Croan, Z. Guo, R. Clark, T. Coldham, and J. Murby. 2000. Evaluation of a DNA finger printing method for determining the species origin of meats. Meat Sci. 54:369-376.

Rea, S., K. Chikuni, R. Branciari, R. Sukasi Sangamayya, D. Ranucci, and P. Avellini. 2001. Use of duplex polymerase chain reaction (duplex PCR) technique to identify bovine and water buffalo milk used in making Mozzarella cheese. J. Dairy Res. 68:689-698.

Reale, S., A. Campanella, A. Merigioli, and F. Pilla. 2008. A novel method for species identification in milk and milk-based products. J. Dairy Res. 75:107-112.

Recio, I., M. R. García-Risco, L. Amigo, E. Molina, M. Ramos, and P. J. Martín-Álvarez. 2004. Detection of milk mixtures in Halloumi cheese. J. Dairy Sci. 87:1595-1600.

Richter, W., I. Krause, C. Graf, I. Sperrer, C. Schwarzer, and H. Klostermeyer. 1997. An indirect competitive ELISA for detection of cows' milk and caseinate in goats' and ewes' milk and cheese using polyclonal antibodies against bovine $\gamma$-caseins. Z. Lebensm. Unters. Forsch. 204:21-26.

Rodríguez, M. A., T. García, I. González, L. Asensio, B. Mayoral, I. López-Calleja, P. E. Hernández, and R. Martín. 2002. Development of a polymerase chain reaction assay for species identification of goose and mule duck in foie gras products. Meat Sci. 65:12571263.

Sasaki, M. 1994. Yak: Hardy multi-purpose animal of Asia highland. Pages 1-5 in Proc. 1st Int. Congr. Yak, Lanzhou, China. Supplement of J. Gansu Agric. Univ., Lanzhou, China.

Tartaglia, M., E. Saulle, S. Pestalozza, L. Morelli, G. Antonucci, and P. A. Battaglia. 1998. Detection of bovine mitochondrial DNA in ruminant feeds: A molecular approach to test for the presence of bovine-derived materials. J. Food Prot. 61:513-518.

Torre, M., M. E. Cohen, N. Corzo, M. A. Rodrı'guez, and J. C. DiezMasa. 1996. Perfusion liquid chromatography of whey proteins. J. Chromatogr. A 729:99-111.

Unseld, M., D. Beyermann, P. Brandt, and R. Hiesel. 1995. Identification of the species origin of highly processed meat products by mitochondrial DNA sequences. PCR Methods Appl. 4:241-243.

Urbanke, W., W. Luf, and E. Brandl. 1992. Einsatz der HPLC bei der verfalschungskontrolle von milch und michprodukten verschiedener species. Z. Lebensm. Unters. Forsch. 195:137-142.

Wang, Y. S., and S. X. Zou. 1995. Protein in milk. Pages 1-48 in Biochemistry of Milk. Jilin Univ. Press, Changchun, China.

Wiener, G., J. L. Han, and R. J. Long. 2003. Origins, domestication and distribution of yak, and production characteristics of yak Pages 2, 136-137 in The Yak. 2nd ed. Regional Office for Asia and the Pacific of the Food and Agriculture Organization of the United Nations, Bangkok, Thailand. 